\title{
A MORE LIBERAL AND ECONOMIC, AND A LESS SOCIAL, APPROACH: THE IMPACT OF RECENT ECJ RULINGS
}

\author{
Nada Bodiroga-Vukobrat* \\ Hana Horak ${ }^{* *}$
}

\begin{abstract}
Summary: This paper examines the interaction between the labour market, social standards and the European Social model on the one hand, and the freedom to provide services on the other. First, the authors analyse whether the Viking and Laval judgements define fundamental human rights as directly opposing fundamental economic freedoms in the internal market. Second, in the context of globalisation, EU enlargement, and the development of the so-called flexicurity model, they gauge to what extent the process of establishing social standards conflicts with employment strategy. The authors further concentrate on the function and legitimacy of the right to collective action in the light of the open methods of coordination. They seek to provide an answer to whether the Viking and Laval cases represent another step towards the erosion of the European Social Model.
\end{abstract}

\section{Introduction}

Interaction between the labour market, social standards and the European Social Model on one hand, and the freedom to provide services on the other, poses a number of controversial questions.

Among the frequently asked questions are the following: what defines a social Europe? Is the European Social Model ${ }^{1}$ a myth or reality? How is it possible to ensure the sustainability of the European Social Model?

Do the Viking and Laval judgments define fundamental human rights as directly opposing fundamental economic freedoms in the internal market? And secondly, in the context of globalisation, EU enlargement, and the development of the so-called flexicurity model, to what extent does

\footnotetext{
" Department of European Public Law, Faculty of Law, University of Rijeka.

"* Faculty of Economics, University of Zagreb.

1 A quick search on Google for the phrase "European Social Model" turns up more than 271,000 hits. If you type in European Social Model + success" you get 93,000 results. So far so good, you might think. But "European Social Model + unemployment" turns up some 98,000 pages. For more, see 'Beyond the European Social Market Model' <www.openeurope.or.uk/research/fullbook/pdf> accessed 10 May 2008.
} 
the process of establishing social standards conflict with employment strategies?

As we can see, the questions are abundant. The answers, on the other hand, are neither simple nor unambiguous, but are rather quite complex.

If we take the Lisbon strategy as our initial reference, its strategic goal is for the EU 'to be (by 2010) the most competitive and dynamic knowledge based economy in the world capable of sustainable economic growth, more and better jobs and greater social cohesion'. ${ }^{2}$ The search for a definition reveals that the Presidency Conclusions of the Barcelona European Council identify the European Social Model as one based on good economic performance, a high level of social protection and education and social dialogue'. ${ }^{3}$

The European Social Model is usually understood as a vision of society that combines sustainable economic growth with ever-improving living and working conditions (employment, good quality jobs, equal opportunities, social protection for all, social inclusion and involving citizens in the decisions that affect them). ${ }^{4}$

European economies are facing both external and internal pressures that have strained the sustainability of its social models, due to the pressures of globalisation. As a result, increased flexibility in the labour market has prompted the EU to look for the path to solve the problems.

In addition, the $2004 \mathrm{EU}$ enlargement brought specific problems. States with a lower level of social protection at work, and with poorer social and living standards have become Member States. Has neo-liberal capitalism, together with the values it promotes, 'pushed' the European Social Model to the edge?

What about collective agreements, a constituent of the European Social Model, in view of the fact that the collective action considered as a 'restriction to the free provision of services' may acquire different connotations? ${ }^{5}$

\footnotetext{
2 Presidency Conclusions of the March 2000 Lisbon European Council.

3 See para 22 of the Presidency Conclusions of the March 2002 Barcelona European Council.

4 In the ETUC's (European Trade Union Confederation) view, social dialogue, collective bargaining and workers' protection are crucial factors in promoting innovation, productivity and competitiveness <www.etuc.org> accessed 12 May 2008.

5 'The weighing of economic freedoms against fundamental rights that the Court is asked to carry out is very similar if the merits concern the indirect State liability or in the (today still hypothetical) case of liability of private individuals for infringing TEC rules. What changes (beside the effects of those appraisals) is that in the first case, even though the fundamental right exercised by private individuals is considered lawful, the State could nonetheless be held liable if it has not adopted all the measures that are necessary and compatible with the
} 
If we look at the history of collective bargaining and the reinforcement of social dialogue between employers, trade unions and the Community, we notice that they have developed at a sectoral as well as intersectoral level. This was especially true during economic recession, when social dialogue was accepted as one of the desirable social and political initiatives and goals. Jacques Delors, Commission Chairman at the time, formulated the idea of social dialogue as an instrument for shaping social policy: 'collective bargaining must remain one of the pillars of our economy, and every effort must be made to ensure harmonisation at Community level. That is the reason why I presented the idea ... of European collective bargaining, which will ensure the requisite frame for achieving the broad market'. ${ }^{2}$

A new issue arises: could this statement be true after the recent judgements of ECJ?

In the path towards further European enlargement and the deepening of the integration process among the present Member States, the creation of a new culture of industrial relations will help European economic subjects in the process of creating an environment where economic subjects from the EC will be competent global players in the merciless world of market competition.

This article will present the issue of social standards within the context of globalisation and europeanisation. One section analyses collective bargaining and the conclusion of collective agreements. Special attention will be given to the character of this process and the social dumping issue, as well as the impact of the recent judgements of ECJ on minimum social standards. The article will also examine the function and legitimacy of the right to collective action in the light of the open methods of coordination, and aims to provide an answer to whether the Viking and Laval cases represent another step towards the erosion of the European Social Model.

\section{Globalisation versus the europeanisation of law and social standards}

Globalisation in general not only includes integration over and above the borders of individual markets, but also the processes which are not defined by the market, and radically shapes human life.

\footnotetext{
exercise of that right in order to remove the obstacle or reduce its impact on inter-Community exchanges. It can therefore be concluded that the 'immunity' of a collective action from the constraints of Article 49 TEC depends on its qualification as fundamental right in the Community legal order. However even in such a case, the Court of Justice is not deprived of its power to appraise the modalities of exercise of the right so as to weigh it against the fundamental freedoms of the Treaty that have allegedly been infringed' G Orlandini, 'Right to Strike, Transnational Collective Action and European Law: Time to Move On?' (2007) Jean Monnet Working Paper 8/07 23.

6 'The Social Dialogue - Euro Bargaining in the Making?' (1992) 220 EIRR 25-27.
} 
According to Waters, globalisation is 'a social process in which the constraints of geography on social and cultural arrangement recede and in which people become increasingly aware that they are receding. ${ }^{7}$ The OECD defines globalisation '... as a process in which economic markets, technologies, and communication patterns gradually exhibit more 'global' characteristics, and less 'national' or local ones'. ${ }^{8}$ Hamouda defines the term as a relative category: 'economic globalisation... is an acceleration of capital integration beyond national borders'. ${ }^{9}$

Globalisation ${ }^{10}$ is the overriding reason for change which compels far-reaching reforms, both worldwide and in the EU. The economic phenomenon of globalisation builds up great political and social devastating power. One can wonder whether globalisation jeopardises social policy and democracy. This is primarily an economic phenomenon which influences other areas (social policy, policy, law, culture, the media).

According to the definition of the Group of Lisbon (1996), a distinction should be made between the terms internationalisation and globalisation: 'Globalization refers to a multiplicity of linkages and interconnections between the states and societies which make up the present world system. It describes the process by which events, decision, and activities in one part of the world come to have significant consequences for individual and communities in quite distant parts of the globe. Globalization has two distinct phenomena: scope (or stretching) and intensity (or deepening). On the one hand, it defines a set of processes which embrace most of the globe or which operate worldwide; the concept therefore has a spatial connotation. On the other hand it also implies an intensification of the levels of interaction, interconnectedness or interdependence between the states and societies which constitute the world Community'. ${ }^{11}$

The trend of the europeanisation of the law of the EU Member States is characteristic and fairly clear. However, the relation between the europeanisation and globalisation of law provokes some doubts.

\footnotetext{
7 M Waters, Globalization (Routledge, New York 1995) 3.

8 OECD, 'Economic Globalization and Environment' (1997) 19.

9 OE Hamouda, 'Economic Integration: ‘Gobble-ization' or Partnership: The Case of Southern Europe in Th Georgakopoulus, Ch Paraskevopoulus, J Smithin (eds), Economic Integration Between Unequal Partners (Aldershot, 1994) 188.

${ }^{10}$ Although the concepts of internationalisation, multi-nationalisation and globalisation are generally and often formulated in a confusing way, they refer to different processes and phenomena. More important, they imply different actors, playing the game with different rules, and they have a significantly different impact on strategies, policies and societies.

11 Group of Lisbon, Limits to Competition (MIT Press, Cambridge, Mass 1996); Die Gruppe von Lissabon, Grenzen des Wettbewerbs (München 1997). See more in K Hübner, Der Globalisierungskomplex (Sigma, Berlin 1998) 19.
} 
Snyder ${ }^{12}$ perceives the globalisation and europeanisation of law as both friends and rivals, claiming that these two processes complement, partially overlap, complete, and reinforce each other. At the same time, they represent a multiple network of legal orders in a constant interlude between national, European, supranational and international law. On the topic of the europeanisation of law and globalisation, Voigt ${ }^{13}$ and Kreile $^{14}$ hold that the internal market is a 'laboratory of globalisation' of law, while Nahamowith considers the europeanisation of law as the first step of globalisation. ${ }^{15}$ However, we should agree with Voigt that these are two distinct processes, considered as such by scientific analysis. ${ }^{16}$

The globalisation of law can be understood as the removal of barriers to its scope of application, ${ }^{17}$ and the europeanisation of law as its regionalisation. Ultimately, they both have the same goal - the denationalisation of law.

However, another issue arises: is this process detrimental to European social standards and the European Social Model?

The Anton Hemerijck Report, during the Netherlands' Presidency in 1997, is significant in this respect, stressing the concept of 'social policy as a productive factor' and also stating 'if social cohesion and stability are thus recognised as productive resources, then surely the contradiction between social justice and economic efficiency break down. Social policy can then no longer be perceived as leading to consumption-related benefits, taken out of an efficient economy by distributive politics. Social policy itself becomes a productive resource which, instead of countering economic policy by protecting or 'decommodifying' labour, comes to play a part in improving the economy's performance potential. From this perspective, social policy and economic performance are closely, perhaps even indissolubly, interconnected'. ${ }^{18}$

\footnotetext{
12 F Snyder, 'Europeanisation and Globalisation as Friends and Rivals: European Union Law in the Global Economic Network' in F Snyder (ed), The Europeanisation of Law (Hart Publishing, Oxford 2000) 293.

13 R Voigt, 'Globalisierung des Rechts: Entsteht eine dritte Rechtsordnung?' in R Voigt, Globalisierung des Rechts (Nomos, Baden-Baden, 2000) 25.

14 M Kreile, 'Globalisierung und europäische Integration' in W Merkel, A Busch Demokratie in Ost und West (Frankfurt / Main, 1999) 605-623.

15 P Nahamowitz, 'Das Europarecht als 'teilglobalisiertes' Rechtssystem: Genügt der EGVertrag den Anforderungen der 'Globalisierung'? in R Voigt Globalisierung des Rechts (Nomos, Baden - Baden 2000) $141 \mathrm{ff}$.

16 R Voigt, 'Globalisierung des Rechts: Entsteht eine dritte Rechtsordnung?' (n 13) 25.

17 L Brock, M Alber, 'Entgrenzung der Staatenwelt. Zur Analyse weltgesellschaftlicher Entwicklungstendenzen' (1995) 2 Zeitschrift für internationale Beziehungen 261.

18 The Netherlands' Presidency of the EU, Social Policy and Economic Performance (The Hague Ministerie van Sociale Zaken en Werkgelegenheid 1997) 87.
} 
The Wim Kok Level Group Report on the Lisbon strategy ${ }^{19}$ gave the key recommendation for 'the Member States to focus on growth and employment in order to underpin social cohesion and sustainable development'.

The question remains whether it is possible to achieve the Lisbon goals through balanced efforts on both the economic and social front.

The EC document has attracted attention and criticism from both the professional and general public. Namely, on 22 November 2006 the Commission of the European Communities issued a Green Paper on 'Modernising labour law to meet the challenges of the $21^{\text {st }}$ century'. ${ }^{20}$

In its introduction, it states that the Commission proposals contribute to applying the Lisbon Strategy. ${ }^{21}$ It further states that the political challenges, technical development and globalisation require new flexible forms in labour law (regarding working time, the form of labour contracts, etc). The intention was, on the one hand, to prompt debate and find optimal solutions, and, on the other hand, to ensure workplace security. It seems that the authors of this document believe that flexicurity is at the same time a magic word and a solution.

The Green Paper raised issues that will be even more pronounced in the coming period; notably, the issue of standard and atypical labour contracts, the issue of consigned workers, especially in the domain of atypical employment relations and their employment status. Even the European Parliament has expressed its view in its Conclusion of 11 July $2007,{ }^{22}$ followed by the Report on this document by the rapporteur Jacek Protasiewicz. ${ }^{23}$

Concurrently, with the discussion of the Green Paper, the Commission has promoted the concept of flexicurity.

The Commission's Communication to the European Parliament, the Council, the European Economic and Social Committee and the Committee of Regions of 27 June 2007 proposes joint principles of flexicurity. All

\footnotetext{
19 Facing the Challenge: The Lisbon Strategy for Growth and Employment. Report from the high level group chaired by Wim Kok (2004).

20 KOM (2006) endgültig.

21 Lisbon Presidency Conclusions para 5.

22 Entschließung des Europäischen Parlaments vom 11. July 2007 zu einem moderneren Arbeitsrecht für die Herausforderungen des 21. Jahrhunderts (2007/2023(INI)) http:// www.europaparl.europa.eu/sides/getDoc.do?pubRef=-//EP//TEXT+TA+P6-TA-20070339+0+DOC+XML+VO//DEktlanguage $=\mathrm{DE}$.

23 Report on Modernising Labour Law to Meet the Challenges of the 21 st century (2007/2023(INI)), Committee on Employment and Social Affairs http://www.europarl.eu-

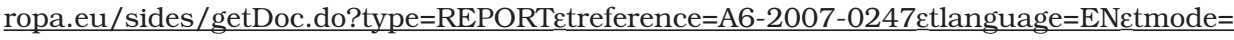
XML.
} 
Member States have to accept the principles. ${ }^{24}$ The following elements of flexicurity are proposed: flexible and admissible agreements (contracts) through modern labour legislation, collective agreements and forms of workers' associations, comprehensive lifelong learning strategies, efficient and active policy measures for the labour market, and modern system of social security.

Apart from the above, the $2004 \mathrm{EU}$ enlargement also raised some specific issues. States with a lower level of social protection at work, and with lower social and living standards became Member States. ${ }^{25}$ Of course we have to be aware that liberalisation of the market also means liberalisation of national rules, and that it opens specific questions regarding the market and the participants in it.

The European Court of Justice interprets extensively economic freedoms in a manner to actually secure basic personal and social rights. The EC law on free movement involves the (horizontal) distribution of regulatory competence between the EU Member States. It is a rather difficult task to define the field of application of the rules, especially in the economic context where services are almost indivisible or tightly connected to goods. It is particularly difficult to demarcate whether restrictions are an infringement of the rules concerning the freedom to provide services or the freedom of establishment, ${ }^{26}$ or whether to apply the rules on the freedom to provide services or the freedom of establishment in the EU law.

The distinction between the rules which apply to the freedom to provide services and the freedom of establishment ${ }^{27}$ is based on ambivalent criteria, given the fact that the economic activities that are performed may be covered by the rules of both freedoms. Establishment means the actual performance of economic activities, continuously and permanently, through permanent establishment in another Member State over an indefinite period of time.

${ }^{24}$ KOM (2007) 359 endgültig <http://ec.europa.eu/employment_social/employment_strategy/pdf/flex_comm_de.pdf>.

25 'The average income per head in the 10 new Member States was well less than half of the average income level in the EU-15, the employment rate, still low with $64.3 \%$ in 2002 for the EU-15, was reduced to 63\% for the EU-25; the 10 new Member States reached an employment rate of $62.4 \%$, taking the enlarged EU even further from its $70 \%$ employment target' Stefaan Hermans, 'The Social Agenda of the European Union and the Modernisation of the European Social Model' (Winter 2005) 33 Collegium 5.

${ }_{26}$ V Hatzopoulos, 'Recent Developments of the Case Law of the ECJ in the Field of Services' (2000) 37 CML Rev 45.

${ }^{27}$ Article 43 TEC. In Croatian literature, see more on establishment: E Kucich, 'Right to Establishment and Recognition of the Legal Subjectivity of a Foreign Company According to EU Law and the Law of the Republic of Croatia' (Master's thesis, University of Rijeka 2004) $30 \mathrm{ff}$. 
The Court of Justice set out in its decision in the Gebhard ${ }^{28}$ case two very important rules to distinguish between the term establishment and the free provision of services in the scope of applying one of them. Nowadays, after the ruling of the ECJ, the impact of the Laval judgement is that the Court interprets Article $49 \mathrm{EC}$ in the light of the Posting of Workers Directive. As the so-called Gebhard formula has so far been applied, a restriction on the free movement of services can be accepted only if it pursues a legitimate aim compatible with the Treaty and is justified by overriding reasons of public interest. But even if that were the case, it would still have to be suitable to achieve the objective pursued and must not go beyond what is necessary to attain it (see, inter alia, Case C-55/94 Gebhard [1995] ECR 1-4165). However, in the Laval Case, the proportionality test is applied in a different way. ${ }^{29}$

A consequence of the Laval judgement is that the idea of equal treatment of domestic and foreign service providers as regards wages and employment conditions is put aside by the principle of minimum protection, whereby the host state - the state or the social partners - may not require anything more than the nucleus of mandatory rules. ${ }^{30}$

According to the above, we can say that the ECJ judgments will serve to further increase the flexibility of the labour market to the detriment of social standards.

\section{Collective agreements and collective bargaining: general remarks}

The economic aspects of harmonising the freedom to provide services, market competition, working conditions and the economy in the European Internal Market require applicable and effective forms.

At the present stage of development, European collective labour law is insufficiently unified and we may speak of a certain particularism in this area. Actually, there are still fields of collective labour law today which have remained within the exclusive competence of Member States. ${ }^{31}$

Collective bargaining draws the attention of both the professional and wider audience. Two specific periods may be recognised in the development of collective bargaining. Authors usually indicate that in most

28 Case C-55/94, Gebhard (1995) ECR I-4165, where the activity of a German lawyer had to be determined. He was a member of the German bar association, but was living and performing his activity in Italy, for domestic and foreign clients. For more detail on the Gebhard case, see J Pecotić, 'Freedom of Establishment in the EC Law' (2004) 8 Law and Taxes 66.

29 J Malmberg, 'Collective Agreements and Collective Bargaining: Analyses of the Impact of the European Court of Justice Ruling on Laval \& Viking (26 February 2008) Meeting with the European Parliament's Committee on Employment and Social Affairs, Working Paper 5.

30 Ibid.

31 See Art 137 Section 6 of the EC Treaty (for example, the right to association, the right to cease work, to strike and lock-out). 
states the legislator first accepted and created a legal frame for collective bargaining (validity of contracts, recognition of the right to industrial action). The second dividing point occurred in the period from the early 1970 s to the end of the 1980 s, when states started to play a more dynamic role in collective labour relations. From that moment on, states began to instigate collective bargaining and collaboration between social partners at different levels. ${ }^{32}$

In the legislature of most European Members States, EC collective agreements are defined as formal written agreements whose feature is that they regulate the working conditions of employees. Usually, the parties are employers, a group of employers or an association of employers on one side, and representatives of employees or an organisation of employees (a trade union) on the other side. Denmark and Great Britain do not have a legal definition of a collective agreement. ${ }^{33}$ Denmark does not require a written form of collective agreement, although such agreements are mostly made in a written form. ${ }^{34}$ One more fact should be pointed out. In Italy, Great Britain and the Nordic countries, collective agreements are considered primarily to be private law agreements, whereas in Belgium, Spain $^{35}$ and France they are more tightly connected with public law. It should also be pointed out that the understanding of the nature of collective agreements in German law ${ }^{36}$ lies somewhere between these two solutions. ${ }^{37}$

In the wider sense, collective bargaining is the negotiating process regarding interests, including all sorts of two-sided and three-sided discussions about problems regarding work which, directly or indirectly, affect employees. ${ }^{38}$

\footnotetext{
32 The best example for this is the Auroux legislature in France and the legislation of Spain and Portugal, which contain the obligation to collective bargaining in good faith. This dominant opinion is realised in the Swedish Act on Co-determination at Work.

33 N Bruun, 'The Autonomy of Collective Agreement' in R Blanpain (ed), Collective Bargaining, Discrimination, Social Security and European Integration (Kluwer, The Hague, London, New York 2003) 3.

34 Nielsen describes the Danish concept of collective agreements as 'broad and imprecise'. Ruth Nielsen, European Law (DJØF Publishing, Copenhagen 2000) 116.

35 Guía de la negociación colectiva 2006, Comisión consultiva nacional de convenios colectivos, Ministerio de Trabajo y Asuntos Sociales.

36 P Hanau, K Adomeit, Arbeitsrecht (Luchterhand 2006) 277 ff; Ulrich Zachert, 'Collective Bargaining in Germany' in Comisión Consultiva Nacional de Convenios Colectivos, Collective Bargaining in Europe (Ministerio de Trabajo y Asuntos Sociales, Madrid 2005) 27-51.

37 N Bruun (n 33) 3.

38 See further: E Cordova, 'Collective Bargaining' in R. Blanpain (ed), Comparative Labour Law and Industrial Relations (3rd ed Kluwer, Deventer 1987); R Blanpain (ed), Comparative Labour Law and Industrial Relations in Industrialized Market Economies (5th edn Kluwer, Deventer 1993).
} 
Collective bargaining in the stricter sense includes the negotiating process of negotiations between employers and employees, as well as agreements which contain binding rules. ${ }^{39}$

If we analyse the practice of the EC Member States, it is evident that collective bargaining has mostly been used as a means to define standards and advance legal standards. It is known that in Denmark collective agreements are the foundation for guaranteeing rights and high labour standards. As some authors say, ${ }^{40}$ collective agreements in Denmark and Sweden might be described as the autonomous collective agreements model: the exclusive responsibility of the trade unions to safeguard a general level of wages and employment conditions. At the same time, in Great Britain collective agreements are not legally binding between the parties.

On one hand, we have Member States such as Belgium, France, Germany and Greece where the provisions of collective agreements may be given an erga omnes effect or a wider legal effect by law. ${ }^{41}$ This is in contrast to other legislatures which are not familiar with the institute of widening the application of a collective agreement.

Gorelli, Valverde and Gordillo point out four technical problems which appear in collective bargaining, relating to the:

1. potential subjects of collective bargaining;

2. procedure to be followed in collective bargaining

3. obligations that these agreements carry, and

4. problems of articulation and complementation between European collective agreements and national regulations. ${ }^{42}$

We can agree with those ${ }^{43}$ who hold that the Viking and Laval cases concern delicate matters of how to balance social policy objectives with economic freedoms.

As its most important conclusion, the ECJ must provide a truly constitutional answer on how to settle conflicts between the social structures of Member States that still remain within their own area of competence, and the dynamics of EC law that seemingly favours the spirit of

\footnotetext{
39 See further Blanpain Comparative Labour Law and Industrial Relations in Industrialised Market Economies (n 38) 570 ff.

40 Malmberg (n 29) 5.

41 E Cordova (n 38) 298, 329; C Barnard, EC Employment Law (2nd edn OUP, Oxford, New York, 2000) 558.

42 GR Gordillo, J Gorelli Hernández, A Valverde, Marco laboral y relaciones colectivas en la Unión Europea, Informe al Consejo Económico y Social de Andalucía (Seville, 2002) 32-33.

43 For example, N Reich, 'Free Movement v. Social Rights in an Enlarged Union: the Laval and Viking Cases before the ECJ' (2008) 9 (2) German Law Journal 128.
} 
free movement to the detriment of the social arrangements of the Nordic countries. ${ }^{44}$

Collective bargaining provides important elements of flexibility, subsidiarity, self-determination and reflexivity in social dialogue in a greater number of EC Member States. Arguments of a social nature refer to the need to avoid social dumping. Collective agreements may guarantee, in a balanced manner, adjustment to the business conditions in a globalised economy and secure minimum social standards. They also enable the creation of effective mechanisms for a culture of social dialogue at work, which is also a general benefit. ${ }^{45}$

The contractual parties usually determine the content of collective bargaining and agreements. This includes first of all normative dispositions, and contractual or obligatory dispositions. Normative dispositions determine the notions and working conditions which must be respected in each labour contract concluded in a single company (this includes all aspects of work, wages, other benefits, for example leave of absence and vacations, classification of working positions, working hours, informing and consulting employees, participation of employees in decision-making and procedural dispositions). ${ }^{46}$ Contractual and obligatory dispositions cover the rights and obligations of the parties. The most frequent contracted obligation is the one regarding the amicable resolution of disputes ${ }^{47}$ (of an absolute or relative nature). When the parties are obliged to refrain from initiating industrial action, the nature thereof is absolute, ${ }^{48}$ whereas it is of a relative nature when neither of the parties is allowed to initiate industrial action to change the conditions of the collective agreement during the entire period of validity of the collective agreement. The relative obligation to resolve disputes amicably enables trade unions to protect the rights of employees in the event of important changes in the socioeconomic environment. ${ }^{49}$ The authority to conclude collective agreements includes the authority to negotiate, conclude and ratify agreements. The

\footnotetext{
44 Ibid 127.

45 Bruun (n 33) 42.

46 Barnard (n 41) 557ff.

47 The obligation of the amicable resolution of disputes is known in Belgium, Denmark, Germany, Greece, the Netherlands, Luxemburg and Spain. In Spain, the obligation has only an absolute character if it is so agreed between the parties. In France and Italy, the obligation to resolve disputes amicably is rarely included in collective agreements since it is considered to be some sort of limitation of the right to strike. In France, the Labour Act sets out that the parties to a collective agreement are obliged not to do anything which might compromise the truthful implementation of the agreement within the boundaries determined by the agreement itself.

48 R Birk, 'Industrial Conflict: The Law of Strikes and Lock-outs' in Blanpain Comparative Labour Law and Industrial Relations in Industrialized Market Economies (n 38) 413.

49 Barnard (n 41) 557 ff.
} 
necessary authority of associations (employers and trade unions) is given to them by their members, or it arises from the legal regulations of a certain EC Member State.

Collective bargaining is marked by coordination among the negotiating parties. The parties try to accomplish common goals through coordination. Coordination may include procedural questions, as well as substantial questions which shape separate but mutually connected rounds of collective bargaining. Coordination plays the most important role in the decentralised negotiation environment. The process of vertical and horizontal coordination in relation to the challenges of the EU and multinational corporations has recently strengthened in Europe. ${ }^{50}$

The question of coordinating tariff policies and concluding collective agreements is most evident at the so-called Doorn group..$^{51}$ The representative trade unions from Belgium, Germany, Luxemburg and the Netherlands expressed in a common statement in 1998 their will to create tighter cross-border coordination of tariff policies within the member states of the monetary union, highlighting that the goal was the conclusion of such a collective agreement to enable greater employment. Trade unions have agreed to continue the coordination of cross-border policies on wages based on the Doorn formula. ${ }^{52}$

'The Doorn Declaration' contains the first common instructions for collective bargaining (trade unions from different European countries). ${ }^{53}$ There are evident methodological difficulties in the interpretation of collective agreement dispositions or the 'calculation of collective agreement dispositions' values'.

Certain fields of industry, such as the metal industry, have also adopted the 'European coordination rules'. ${ }^{54}$

\footnotetext{
50 Ibid. 512-513.

51 On 7 and 8 September 2000, more than 50 trade union representatives from Belgium, Germany, Luxemburg and the Netherlands met for the 4th time at a so-called joint meeting of the Doorn group'. The group borrowed the name from the city of Doorn in the Netherlands.

52 See further M Schmidt, 'Das Arbeitsrecht der Europäische Gemeinschaft' (Nomos, Baden-Baden 2001) 332.

53 They refer to: accomplishing such agreements regarding the growth or productivity and wage increase; the increase of the buying capacity of employees and measures to create new working places (for example diminishing working hours); regular informing and consultation regarding the development of collective bargaining. Blanpain Comparative Labour Law and Industrial Relations in Industrialized Market Economies (n 38) 567 ff. See also <www. eurofound.ie> accessed 24 January 2007.

54 European coordination rules contain principles which the national negotiators will uphold in order to avoid unfair market competition and social dumping with regards to wages and working conditions. The European Metalworkers Federation (EMF) points out that it is important for trade unions to maintain full autonomy and also full responsibility regarding the implementation of collective agreements, respecting, of course, the different national circumstances and the conditions which exist in national legal systems.
} 
Collective bargaining may be divided into centralised and decentralised bargaining. Centralised bargaining means coordinated negotiation. Up to the beginning of the 1980s, this was a feature of the Scandinavian countries and Austria, Australia and New Zealand. This way of negotiating has kept its particular significance in Finland, Denmark and Belgium, and also Spain, Ireland and France. Most European countries traditionally opt for collective bargaining at the level of one field of industry. ${ }^{55}$

In December 2000, the ETUC Executive Committee confirmed the guidelines on the coordination of wage bargaining. ${ }^{56}$

\section{Impact of the recent ECJ rulings}

One of the most important features of the regulatory function of collective bargaining is the power to derogate from the mandatory provisions of labour legislation.

Derogatory powers are displayed in various kinds of labour legislation in the form of derogation clauses, as well as in the so-called 'opening clauses' or 'hardship clauses' and 'salary opt-out clauses'.

Derogation clauses in Sweden and Finland are quite commonly negotiated by labour organisations representing employees at national level. Such organisations are empowered under the law to agree on derogation from mandatory provisions in a collective agreement which applies nationwide.

Another example of derogatory power is the so-called 'opening clauses' or 'hardship clauses' known in Austrian and German law. Opening clauses provide a restrictive possibility for companies to diverge from collectively defined minimum standards.

55 GJ Bamber, P Sheldon, 'Collective Bargaining: Towards Decentralization?' in R Blanpain (ed), Comparative Labour Law and Industrial Relations in Industrialized Market Economies (8th rev edn Kluwer Law International, The Hague 2004) 516 ff.

56 This document contains three main goals: to enable trade unions to give general instructions on a European level in relation to collective bargaining regarding wages, as a response to the policy of the European Commission and the European Central Bank, and to affect the 'macro-economic dialogue' on a European level;

to avoid situations which may lead to social dumping and wage dumping and divergence in Europe; and to coordinate demands regarding wages in Europe, in particular in countries which are members of the European monetary union, and bring convergence criteria to a higher level, particularly in respect of living standards. The formula contained in the said document should also be pointed out: 'nominal wage increases should at least exceed inflation, while maximising the proportion of productivity allocated to the rise in gross wages in order to secure a better balance between profits and wages, and any remaining part of productivity should be used to fund other aspects in collective agreements, such as qualitative aspects of work where these are quantifiable and calculable in terms of cost' Guideline on Collective Bargaining Coordination (ETUC executive committee) <www.eurofound.ie $>$ accessed 2 January 2007. 
In Spain, derogation powers take the form of 'salary opt-out clauses', allowing financially jeopardised companies to opt-out of potentially harmful provisions of collective agreements. ${ }^{57}$

We have pointed in the introduction to the particularities of collective agreements and collective bargaining. It is particularly important in this paper to further focus on different categories of collective bargaining in Sweden. There are four specific situations where the factual background is actually different. This important difference comes down to what happens if the social partners disagree: first - core collective bargaining; second - collective bargaining according to the co-determination model; third - also the co-determination model, but negotiations take place against a background of reinforced trade union influence; and fourth - collective bargaining based on semi-mandatory law.

Even before the Viking and Laval judgments, Norberg and Numhauser-Henning ${ }^{58}$ indicated the problem in the fourth way of collective bargaining, highlighting that: 'To protect individuals rights, to use collective agreements as instruments of implementation does not absolve the Member State from taking full responsibility for guaranteeing full coverage of the Directive. The semi-mandatory technique frequently used in Sweden to implement Directives seems to address these issues adequately. Where the traditional autonomy of the social partners is more demanding - as is the case with wage setting - statutory intervention is considerably less attractive, though. To implement the rules on minimum legislation in the Posting Directive, Sweden thus relies on Lex Britannia, ${ }^{59}$ leaving the trade unions to combat social dumping by means of collective bargaining and industrial action in a legal setting which seems to open for discriminatory practices towards foreign employers. The statute-based immunity for collective agreements explicitly stated in national competition law may also - in combination with extensive collective bargaining rights within the area of managerial prerogatives - occasionally produce conflicts with EU law.'

But let us take one step at the time. Recent judgements have caused great controversy and disagreement.

\footnotetext{
57 Bruun (n 33) 14.

58 P Norberg and A Numhauser-Henning, 'Collective Bargaining in Sweden' in Comisión Consultiva Nacional de Convenios Colectivos, Collective Bargaining in Europe (Ministerio de Ttrabajo y Asuntos Sociales, Madrid 2004) 240-273; see also Bruun (n 33) 32 and 33.

59 The risk of social dumping is when foreign employers bring their employees to Sweden to perform work. It has been dealt with by the Co-Determination Act and its rules on Lex Britannia. Lex Britannia thus applies even when Swedish law otherwise does not apply, for instance to foreign ships temporarily visiting a Swedish port. It also applies to situations covered by Council Directive 96/71/EC on the posting of workers. The law implementing this directive indicates statutory minimum conditions in cases covered by it. However, there are no statutory minimum wages in Sweden and this is where industrial action and Lex Britannia come into the picture.
} 


\section{IV.1. More economic, less social?}

The Internal Market should represent the end of obstacles on the free movement of services, capital, goods and workers. ${ }^{60}$ Analysing the relation of labour law within the context of economic freedoms, Gerard Lyon-Caen talks of the 'infiltration of competition law into labour law'. ${ }^{61}$

In 1992, Lord Wedderburn claimed that ' $(\mathrm{H})$ istory writes the grammar of the labour law system which still survives even though subsequent social events have changed the story'. ${ }^{62}$

The same author in 2007 stated that 'The discrepancy between the growing power of employers benefiting from European transnational economic integration, and the relative weakness of a declining labour movement which remains largely confined to national boundaries in its collective bargaining and collective action has profound implications for the future of the European Union'. ${ }^{63}$

For the purpose of creating a balance between the social rights of workers and the market freedoms of employers, S Sciarra recommends the use of judicial escamotage (judicial juggling). ${ }^{64}$

This hardly comes as a surprise when we remember that the labour law, including European labour law, has been a fairly protected area. As Malberg rightly claims: 'in the shadow of the internal market a territorial struggle is in progress over where labour law ends and economic rules take over'. ${ }^{65}$

The Laval and Viking cases are an illustration of this struggle. These judgments also call into question social standards and the social model, since, in the opinions of the Advocates General (characteristic in both cases), it can be concluded that the Treaty's market freedom articles could be directly or indirectly interfered with by industrial action, but that such trade union action could in some circumstances be 'justified', so long as it were 'proportional' or 'appropriate'.

However, let us turn to the ECJ judgements.

\footnotetext{
60 MG Garofalo, 'Un Profilo Ideologico del Diritto del Lavoro?' in Studi di Lavoro: Scritti in onore di Gino Giugni (Cacucci 1999) 453 and 466.

61 G Lyon-Caen, 'L'infiltration du droit Travail par le droit de la Concurrence?' (1992) Droit Ouvrier 313. See also A Lyon-Caen, 'Droit Social et Droit de la Concurrence' in Orientations sociales du droit contemporaine: Ecrits en l'honeur du Prof Jean Savatier (Paris 1992).

62 L Wedderburn, Freedom of Association and Community Protection: A Comparative Inquiry into Trade Union Rights in the Member States of the EC and into the Need for Intervention at Community Level (Unpublished Report for the European Commission).

63 L Wedderburn, 'Labour Law 2008: 40 Years On' (2007) 36 Industrial Law Journal 397.

64 S Sciarra, 'Market Freedom and Fundamental Rights' in B Hepple (ed), Social and Labour Rights in a Global Context (CUP, Cambridge 2002) 95-121.

65 Malmberg (n 29) 1.
} 
In the Laval and Viking cases, the ECJ actually gave priority to fundamental market freedoms in relation to trade union collective actions. The first clarification of the judgements is that the right to collective action is not excluded from the scope of the application of Article $49 \mathrm{EC}$ (on the free movement of services) or Article $43 \mathrm{EC}$ (on the freedom of establishment). Further, Articles 43 and $49 \mathrm{EC}$ are capable of conferring rights on a private undertaking which may be relied on against a trade union or an association of trade union.

Both cases examine the issue of trade union measures against "social dumping'. Actually, the issue arising from both cases is whether trade union activities (strikes and boycotts) prevent employers from using their market freedoms to gain competitive advantage, based on the wage gap between 'old Member States' and 'new Member States'.

We believe that it is necessary to recall the time when the adoption of the so-called 'Monti regulation' was being prepared. There was tension between the regime on the free movement of goods on one hand, and national industrial relations on the other. It was found that industrial action carried on at national level might factually hinder the free movement of goods. ${ }^{6}$

Therefore, one should remember the judgment in case C-265/95 concerning acts of violent destruction by French farmers regarding the import of Spanish fruit and vegetable, and the question of corresponding measures aimed at prevent the violence. The ECJ took the position that the French Republic had infringed its obligations by failing to adopt all necessary and proportionate measures to prevent the free movement of fruit and vegetable from being obstructed by the action of private individuals.

There was debate regarding the adoption of a Council Regulation. The proposed regulation intended to cover at least some industrial action and gave the Commission competence to intervene in national procedures when obstacles to the free movement on goods occurred at national level. There was also the question of the immunity and autonomy of national industrial relations systems in relation to the fundamental principle of the free movements of goods.

The debate resulted in a clear position which served as a guideline for interpretation in conflict situations (Regulation 2679/98/EC Art 2):

'The regulation may not be interpreted as affecting in any way the exercise to fundamental rights as recognised in Member States, including the right or freedom to strike. These rights may also include the right or freedom to take the other conditions covered by the specific industrial relations system in Member States. ${ }^{97}$

\footnotetext{
66 N Bruun and B Veneziani, 'The Right or Freedom to Transnational Industrial Action in the European Union' in A Legal Framework for European Industrial relations (ETUI, Brussels 1999) 542.

67 Regulation 2679/98/EC (7 December 1998).
} 
The ECJ judgement of 21 September 1999 in the Albany case gave priority to solidarity action and collective bargaining autonomy over the four market freedoms, while the Schmidberger judgement came out in favour of consideration case by case.

Both Advocates General in the Viking and Laval cases follow the Schmidberger line, ${ }^{68}$ and the positions taken in the Omega case, ${ }^{69}$ which is not surprising.

Advocate General Maduro ${ }^{70}$ claims that although TEC achieved the common market, it also created its negative effects.

Kochner rightly claims that it seems that we all forget the relations in the 'social contract' and that we should be able to accept the negative consequences, along with the specific working conditions. ${ }^{71}$

\footnotetext{
68 The Court has also recently dealt with fundamental rights as constraints to economic freedoms in the Schmidberger case. The issue arose regarding the demonstration organised by an environmental group, implicitly permitted by Austrian authorities, which resulted in the complete closure of the Brenner motorway to traffic for almost 30 hours. Schmidberger, a German-based international carrier, claimed damages against the Republic of Austria, arguing that the failure of Austrian authorities to ban the demonstration constituted a restriction on the free movement of goods. The ECJ ruled that the restriction of the free movement of goods can be justified by the legitimate interest in the protection of fundamental human rights, such as the protesters' right to freedom of expression and freedom of assembly. However, the ECJ points out that a fair balance must be struck between all the interests involved, and that it is upon the Court to determine from the circumstances of the case "whether the restrictions placed upon intra-Community trade are proportionate in the light of the legitimate objective pursued' (para 82). The "proportionality" in the case in which the derogation from a fundamental freedom under the TEC is based on the need to protect another fundamental right acquires a "bilateral" significance, since also the latter admits limitations that are necessary and proportionate to the objective pursued.

69 In the Omega case, the Court ruled that the protection of a fundamental right comes under the grounds of public policy that, pursuant to Article $55 \mathrm{TEC}$, justify a restriction of the freedom conferred by Article 49 TEC. German authorities prohibited a German company from operating a game, whose object was firing on human targets using a laser beam or other technical devices (so called 'playing at killing'), as dangerous to public order.

Since the German company used the equipment and technology provided by a British company, the issue of infringement of Community law arose, particularly Articles 49 to 55 TEC on the freedom to provide services, and Articles 28 to 30 TEC on the free movement of goods. The ECJ held that the respect of human dignity, one of the German constitutional principles, constitutes a legitimate interest capable of justifying restriction of the freedom to provide services, if the measure is proportionate to the goal pursued and if it is deemed necessary.

70 'Although the Treaty establishes the common market, it does not turn a blind eye to the workers who are adversely affected by its negative traits. On the contrary, the European economic order is firmly anchored in a social contract: workers throughout Europe must accept the recurring negative consequences that are inherent to the common market's creation of increasing prosperity, in exchange for which society must commit itself to the general improvement of their living and working conditions, and to the provision of economic support to those workers who, as a consequence of market forces, come into difficulties' (Opinion GA Maduro, 23 May 2007, C - 438/05 Viking para 59).

71 E Kochner, 'Kollektivverhandlungen und Tarifautonomie-welche Rolle spielt das europäische Recht' (2008) 1-2 AuR 16.
} 
However, the next issue is one relating to social values and how to protect them. The protection of employers and their working and social rights and social standards are likely to become even more significant in the future.

It seems very important to emphasise the position taken by GA Maduro, who claims that:

[a]lthough the right to take collective action, including the right to strike, must therefore be recognised as a fundamental right which forms an integral part of the general principles of Community law the observance of which the Court ensures, the exercise of that right may none the less be subject to certain restrictions. As is reaffirmed by Article 28 of the Charter of Fundamental Rights of the European Union, those rights are to be protected in accordance with Community law and national law and practices. In addition, as is apparent from paragraph 5 of this judgment, under Finnish law the right to strike may not be relied on, in particular, where the strike is contra bonos mores or is prohibited under national law or Community law (para 44, the Viking case).

The issue at stake was the aim, ie the protection of jobs, and the issue of maintaining and protecting social standards. This is essentially a question of socio-legal protection, as a result of re-flagging, and the issue of laying off employees. According to the opinion of GA Maduro, if the reflagging does not jeopardise jobs, then collective action is not aimed at the protection of employees' rights.

The situation is interesting since ITF and its campaign against flags of convenience is at play here. We would like to point to paragraph 88 of the judgement:

in relation to the collective action seeking to ensure the implementation of the policy in question pursued by ITF, it must be emphasised that, to the extent that that policy results in ship owners being prevented from registering their vessels in a State other than that of which the beneficial owners of those vessels are nationals, the restrictions on freedom of establishment resulting from such action cannot be objectively justified. Nevertheless, as the national court points out, the objective of that policy is also to protect and improve seafarers' terms and conditions of employment. ${ }^{72}$

72 See also para 89 Viking: 'However, as is apparent from the file submitted to the Court, in the context of its policy of combating the use of flags of convenience, ITF is required, when asked by one of its members, to initiate solidarity action against the beneficial owner of a vessel which is registered in a State other than that of which that owner is a national, irrespective of whether or not that owner's exercise of its right of freedom of establishment is liable to have a harmful effect on the work or conditions of employment of its employees. Therefore, as Viking argued during the hearing without being contradicted by ITF in that 
Another issue was whether the trade union has more appropriate means and instruments than the ones used in the present case. ${ }^{73}$

In the present case, it must be borne in mind that, as is apparent from paragraphs 35 and 36 of the present judgment, the collective action taken by FSU and ITF is aimed at concluding an agreement which is meant to regulate the work of Viking employees collectively, and, that those two trade unions are organisations which are not public law entities but exercise the legal autonomy conferred on them, inter alia, by national law.

\section{IV.2. The Viking and Laval cases}

Let us consider the facts in the Viking and Laval cases. Viking

The facts

Viking is a Finnish-based ferry operator. One of its vessels, called Rosella, plies the route between Tallinn (Estonia) and Helsinki (Finland) under a Finnish flag. Estonian vessels operating on the same route with lower wage costs were a direct competition to Viking, and Rosella was running at a loss. In order to gain competitive advantage, Viking's management decided to re-flag the vessel, using the Estonian flag. The decision was also taken to employ Estonian labour in order to take advantage of the fact that wages are lower in Estonia. In response, the Finnish Seamen's Union (FSU - the crew of the Rosella are its members) warned Viking that they might take collective action to stop the re-flagging process. To avoid the danger of being undercut, it also asked the International Transport Workers' Federation (ITF) under its "Flag of conveniences campaign" to ask their members not to start negotiations with Viking unless they were based in Finland. According to this campaign, the ITF affiliates (600 unions in 140 different states) agreed that only trade unions established in the state of beneficial ownership should have the right to

regard, the policy of reserving the right of collective negotiations to trade unions of the State of which the beneficial owner of a vessel is a national is also applicable where the vessel is registered in a State which guarantees workers a higher level of social protection than they would enjoy in the first State'.

73 'As regards the question of whether or not the collective action at issue in the main proceedings goes beyond what is necessary to achieve the objective pursued, it is for the national court to examine, in particular, on the one hand, whether, under the national rules and collective agreement law applicable to that action, FSU did not have other means at its disposal which were less restrictive of freedom of establishment in order to bring to a successful conclusion the collective negotiations entered into with Viking, and, on the other, whether that trade union had exhausted those means before initiating such action (para 87). 
conclude collective agreements covering the vessel concerned. The main purpose of re-flagging, ie to reduce wage costs, would be frustrated if the crew continued to be employed on the conditions laid down by Finnish law and applicable collective agreements.

Viking initiated legal proceedings before the High Court of Justice of England and Wales, the Queen's Bench Division, in order to declare that the action taken by ITF and FSU imposed restrictions on the freedom of establishment contrary to Article $43 \mathrm{EC}$, and alternatively restrictions on the freedom of movement of workers and the freedom to provide services under Articles 39 EC and 49 EC. The Court of Appeal, deciding on the appeal submitted by ITF and FSU against the decision granting the form of order sought by Viking, referred to the Court of Justice under Community law.

\section{The judgement}

The ECJ recognised the right to take collective action, including the right to strike as a fundamental right which forms an integral part of the general principles of Community law. Nevertheless, this right might be restricted, as reaffirmed by Article 28 of the Charter of Fundamental Rights of the European Union which states that it is to be protected in accordance with Community law and national law and practices. Furthermore, the exercise of this right may be subject to certain restrictions.

Laval

The facts

Laval and Partners Ltd is a Latvian construction company which was awarded a public contract for the refurbishment of a school in Vaxholm, Sweden. Laval posted its Latvian workers to Sweden to fulfil the contract, subject to working conditions and other terms agreed with the Baltic trade union. As is standard practice in the Swedish industrial relations system, the Swedish unions (Swedish Building and Public Works Trade Union and its local branch No. 1) started negotiations with Laval in order to sign a collective agreement with regard to wages and other working conditions, which are always laid down by negotiation on a caseby-case basis. Laval did not want to pay the wages requested and refused to sign a collective agreement in Sweden. Following the failure of the Swedish negotiations, the Swedish trade unions took action by blockading the construction site. Solidarity actions then followed from the electricians' trade union. Laval brought the proceedings before the Swedish court to obtain a declaration that the industrial action was unlawful, as 
it represented an infringement of the right to provide services conferred by Article $49 \mathrm{EC}$ and the provision of Directive 96/71/EC concerning the posting of workers in the framework of the provision of services. The Swedish Labour Court referred the case to the European Court of Justice, wishing to ascertain whether Articles 12 EC and 49 EC and Directive 96/71 preclude trade unions from attempting, by means of collective action, to force a foreign undertaking which posts workers to Sweden to apply a Swedish collective agreement.

\section{The judgement}

With regard to the right to strike as a fundamental right and within the scope of the freedoms, the Laval judgement developed the earlier position set out by the Viking ruling. The ECJ again applied the proportionality test and stated that collective action for the protection of the workers of the host State against social dumping may constitute an overriding reason of public interest, which in principle justified a restriction on one of the fundamental freedoms. The means of blockading action by a trade union falls within the objective of protecting workers. But in the actual case concerned, the action could not be justified due to the incorrect implementation of the posting of workers Directive.

Most of the judgement concerns the interpretation of this Directive. The ECJ was of the opinion that negotiation at the place of work, on a caseby-case basis, when minimum rates of pay are not determined in accordance with one of the means provided for by the posting of workers Directive, are not permissible under the Directive. The Court put into question the flexibility of the Swedish collective bargaining system, emphasising the alleged lack of certainty for a business unable to ascertain in advance the conditions it would have to guarantee to its posted workers.

The objective of the Posting of Workers Directive is to lay down a set of mandatory rules for minimum protection to be observed in the host country by employers who post workers to perform temporary work in the territory of a Member State where the services are provided. The ECJ now judges that the Directive limits the level of protection guaranteed to posted workers. Neither the host Member State nor the social partners can ask for more favourable conditions, which go beyond the mandatory rules for minimum protection in the Directive. This is now often referred to as a change from a minimum to a maximum Directive.

In the Laval and Viking cases, the ECJ stated that national employment law lies within the scope of the Community's free movement legislation. This means that no special treatment is applied in the employment law sphere. The judges went even further when they considered that the freedoms can be invoked against trade unions, meaning that employers 
can now take trade unions to court to obtain a judgement on the legality of a collective action.

The ECJ sees the right of trade unions to take collective action as a restriction on the freedom to provide services or the freedom of establishment. Collective action must be justified. It must have a legitimate aim, respond to overriding reasons of public interest and be suitable to attain the objective pursued and not go beyond what is necessary in order to attain it. These conditions are often called the proportionality test, which is now introduced by the court with respect to trade union rights.

The protection of workers is a legitimate interest, which in principle justifies a restriction of one of the fundamental freedoms guaranteed by the Treaty. It is in principle up to the national courts to ascertain whether the objectives pursued by means of collective action concern the protection of workers. However, the court lays out very strict guidelines to national courts with regard to how they have to judge such cases. The question they have to answer is whether the jobs and conditions of employment are really jeopardised or under serious threat by the behaviour of the enterprise.

To combat inferior working conditions of a 'dumping' nature, Swedish trade unions would initiate industrial action against a foreign employer in order to force him or her to sign the applicable Swedish collective agreement. ${ }^{74}$

Regarding the Laval case, we agree with Blanke that the ECJ intervened in the very structures of industrial relations of an individual member state. ${ }^{75}$

Pursuant to Art 137 (4), 'The provisions adopted pursuant to this Article shall not prevent any Member State from maintaining or introducing more stringent protective measures compatible with this Treaty.'

It is a fact that the Member State must regulate the right to strike with a view to Community law and established standards. It seems that the ECJ, without formal authorities, established precise borders regard-

\footnotetext{
74 Lex Britannia states that a collective agreement governed by the Swedish Co-Determination Act takes precedence over collective agreements governed by foreign law and that the legality of industrial action shall be governed by Swedish law alone. The peace obligation is also modified to cover only collective agreements governed by Swedish law. The legislator helps the trade unions combat social dumping by legislating a general reinforcement of the Swedish trade unions' position in the collective bargaining system when they are dealing with foreign employers.

75 T Blanke, 'Die Entscheidungen des EuGH in den Fällen Viking, Laval und Rueffert-Domestizierung des Strelkrechts und europaweite Nivellierung der industriellen Beziehungen' $<$ www.etui-rechs.org/Headline-issues /viking-Laval-rueffert/2-Articles> 5-6. See also T Blanke, 'Streikende Wikinger vor dem Europäischen Gerichtshof' (2006) 1 AuR.
} 
ing the issue of strikes, even though it did refer to Art 2 and Art 3 TEC, as well as the mentioned socio-political goals of the Community.

It also seems that the ECJ intervened in a very flexible system of collective negotiations in Sweden, which will reflect on employees' wages.

Only time will tell whether this case has exposed socio-political deficits in the TEC. We hold that those deficits are obvious, since we also encounter the question whether there is a structural socio-political error, because both in the EC Treaty and the EU Treaty the social rights of employees and their organisations are not, at first sight, as rightly claimed by Kochner, treated with the same value as fundamental market freedoms ('nicht mit gleichem Stellenwert wie die Grundfreiheiten geregelt'), ${ }^{76}$ especially in the context of the relations between Art 11 EHRC and Arts 5 and 6 of the European Social Charter, and within the context of Arts 6 and Art 136 EC Treaty, which represent the most prominent references to these rights.

The future will also raise the question of the conduct of Member States, and their resort to the opt-out clause ${ }^{77}$ regarding fundamental social rights and their obligatory character, especially in the light of the EU Charter of Fundamental Rights.

Another problem is the function and legitimacy of the right of collective action in the light of the open methods of coordination (OMC). In this context, 'deliberative polyarchy' between institutions and civil society is to be observed. The concept of polyarchy is to be connected with permanent imbalance resulting from material and procedural competences, on different lower levels. ${ }^{78}$ Polyarchy has therefore a dual dimension: democratic representation and decentralisation. Deliberativeness marks the adjustment of different positions due to the direct interaction and rational argumentation of participants in the decision process. ${ }^{79}$ Therefore, reflexivity points to the need for the coordination and mutual understanding of functionally distinct groups within a society.

\footnotetext{
76 Kochner (n 71) 16.

77 Protocol (no 30) on the Application of the Charter of Fundamental Rights of the European Union to Poland and to the United Kingdom, OJ C306 of 17 December 2007.

78 S Baric, 'Civilno društvo i regionalna suradnja u kontekstu odnosa Republike Hrvatske s Europskom unijom' in N Bodiroga-Vukobrat and S Baric (eds), Prekogranicna i regionalna suradnja (Rijeka, 2007) 123.

79 O Gerstenberg and C Sabel, 'Directly-Deliberative Polyarchy: An Institutional Ideal for Europe?' in C Joerges and R Dehousse (eds), Good Governance in Europe's Integrated Market (OUP 2002) 292.
} 
Orlandini ${ }^{80}$ does not agree with Novitz ${ }^{81}$ who, 'among the few that have tackled the issue of the relationship between the right to strike and the 'deliberative' model of democracy, concludes that this model is the least capable of providing argument for the legitimacy of the recognition of that right'.

Our position is closer to that of Novitz, because the reflexivity of deliberative polyarchy points to the necessity for the coordination and mutual understanding of functionally distinct groups.

\section{Conclusion}

The related problems of exercising social rights, including attaining the goals of the general social policies established by the EC Treaty, the creation of a European value system, and especially the issues of the relation between national and European fundamental human rights standards, have a national and European dimension.

Both judgements covered in this paper show a more liberal and a less social approach through the certain precedence given to free movement rights over the fundamental right to strike. ${ }^{82}$

The Viking and Laval cases show that a more flexible approach instead of maximum harmonisation would be a better way to solve the problems and imbalance between the social and liberal approach. This

80 'Procedural [law] ensures and legitimates the (open) confrontation between institutions and public (Community, national and local) subjects, social players and private organisations in the OMC framework. Yet also the rights that are protected and enforced by means of the new forms of soft regulation are 'procedural': the right to 'lifelong' learning, to equal opportunities, not to be discriminated on the grounds of one's identity, the new workfare rights, the right to actively look for a job, the right to free access to employment services, the right to reconcile private life and work, the right to income 'continuity' when one does not work, and, on the collective level, the rights of information and consultation, that should feature more cooperative and less confrontational industrial relations thus rendering companies more competitive. The European social citizenship, whose main constituents have been defined by the Nice Charter and that the OMC intends to translate into concrete social policies in the single national systems, should consist of those rights. In this context there seems to be no room for the right of collective action, as it is aimed at settling interests by means of negotiations and not in a 'dialogic' way, and since the weapon of the litigation does not match with the notion of procedural rights.' See more in Orlandini (n 5) 50-53.

81 'It does [...] appear that deliberative democracy calls into question the privileged access of workers' and employers' organizations. Moreover, it seems that their industrial weaponry, including a right to strike, is to be left at the door to the debating chamber, for this would lead to bargaining rather than rational choice. Similarly, conflict within the workplace is also no longer seen as a necessary feature of employment relations. Instead, workers are called upon to lay aside their perception of divergent interests, and instead work together in 'partnership' with management to achieve ends which are of mutual benefit to both. Within this framework, industrial action comes to be seen too confrontational to foster the trust needed for deliberation. It becomes redundant.' See more in T Novitz, International and European Protection of the Right to Strike (Oxford, 2003) 185.

82 Reich (n 43) 128. 
is especially so bearing in mind the efforts to bridge the gap between the old and new Member States and the fact that the social structures in the Member States still remain within their own area of competence.

As the Commission has underlined the importance of the Austrian model in its Green Paper 'Modernisation of labour law to meet the challenges of the $21^{\text {st }}$ century', the question is raised about the always favoured Scandinavian social model. Is it really true that this model may be endangered if EC law interferes in its working by imposing its specific rules on free movement?

Also, concerning the question of deregulation of national labour rules and codification at the European level in relation to social dialogue, we can ask whether collective bargaining and the protection of workers are still key elements in the European Social Model ${ }^{83}$ and how the problems can be solved. There are indeed numerous questions which open a number of new topics.

Is flexicurity one of the more flexible approaches in solving problems in labour law on the supranational level?

It is clear that the neo-liberal concept and globalisation require more elastic forms of typical labour relations than those shown in the Laval and Viking cases. ${ }^{84}$

It seems that the best solution for the preservation of the European Social Model is to return to the principle of differentiated integration. It would thus be possible to tie two requirements: acknowledgement of the differences and integration of the different features, without curtailing the different social standards achieved in Member States. In fact, open methods of coordination (OMC) are following that path. Although originally introduced in the area of employment and social policy, they are increasingly used in other policy areas as well. We find that $\mathrm{OMC}^{85}$ are particularly applicable in this field, since, in essence, the methods allow Member States to keep their formal competence in certain areas, while formulating joint aims at Community level, which can be achieved through a 'soft law' approach (eg benchmarking).

\footnotetext{
83 <www.etuc.org : http://www.etuc.org/a/2771>.

84 We agreed a year ago with S Weatherill and his three critical perspectives: 'Is this 'Better Regulation'? Is this 'Simplification'? Is maximum harmonisation in a horizontal measure of this breadth a step too far in favour of centralisation and against local autonomy in Europe?' S Weatherill, 'The EC Service Directive - why....and why not' (presentation in 'Advanced Issues of European Law' Dubrovnik 2007).

85 D Hodson, I Maher, 'The Open Method as a New Mode of Governance. The Case of Soft Economic Policy Co-ordination' (2001) 39 (4) Journal of Common Market Studies 719746.
} 
The OMC method is sensitive to national, regional and local differences, which are left to Member States' sovereignty, providing at the same time for a sustainable European Social Model.

Apparently, the ECJ does not seem to reflect either of its recent rulings in the light of the European Social Model and available instruments, but rather endorses the opinion that an economic approach and market demands predominate over social ones.

Since it opted for an economic approach, the ECJ should have then taken into account flexicurity principles as an attempt to unite two fundamental needs. Promoting a combination of flexible labour markets and a high level of employment and income security is thus seen to be the answer to the EU's dilemma on how to maintain and improve competitiveness while preserving the European Social Model.

Perhaps we can borrow the topic of the work of Federico Ortino ${ }^{86}$ in the field of International Economic Law 'From 'non-discrimination' to "reasonableness" and add it to European Labour Law to avoid the gap between the liberal and social model.

But the most important question still remains: is it possible to ensure the sustainability of the European Social Model?

The question remains because it is clear that achieving the freedom to provide services and ensuring market freedoms represent a silent erosion of the European Social Model.

86 F Ortino, "From "non-discrimination" to "reasonableness": a paradigm shift in international economic law?' (2005) Jean Monnet Working Paper 01/2005. 